\title{
THE STRUGGLE FOR SOCIAL WELFARE: TOWARDS AN EMERGING WELFARE SOCIOLOGY
}

\author{
MARIUSZ BARANOWSKI ${ }^{1}$ \\ ${ }^{1}$ Adam Mickiewicz University in Poznań, Szamarzewskiego 89 C, 60-568 Poznań, Poland. ORCID: 0000- \\ 0001-6755-9368, Email: mariusz.baranowski@amu.edu.pl
}

\begin{abstract}
The main aim of the article is to outline welfare sociology as a potential sub-discipline of sociology and to discuss the issues of broadly defined social welfare. While in contemporary social sciences the literature concerning welfare often focuses on themes such as happiness (psychology), prosperity (economics), or quality of life (sociology), these themes may be considered too narrow and do not reflect the complexity of the issue. However, if one considers the definition of social welfare through the prism of material and non-material needs, as well as the needs expressed individually and collectively, it is possible to attempt a comprehensive study of this phenomenon. The author uses the definition of social welfare to look at research on (a) welfare state regimes, (b) welfare attitudes and (c) issues of work in contemporary capitalism, all to enable the application of research results within the analysis of the title concept. KEYWORDS: social welfare, welfare scarcity, welfare sociology, well-being, ill-being
\end{abstract}

\section{INTRODUCTION}

The history of all hitherto existing society is the history of social welfare struggles (cf. Marx and Engels [1848] 1948:9). Class struggle, for example, is an important but only a subset of the space/agglomerate of multifaceted battles for social welfare. Although differently conceptualised, the welfare project was, in the past and is today the goal of not only individuals or groups of people, but above all of the complex societies, with their specific social diversity as a consequence of the dominant economic system. The influence of capitalism on social welfare in the broadest sense - sometimes referred 
to as prosperity (Marshall 1961, Pontusson 2005), wealth (Daunton 2007) or affluence (Galbright [1952] 1998) - as well as its lack, determines the core of interest in contemporary social sciences. Even if the concept itself is reduced to the requirements of theoretical-methodological orientation of a particular discipline or sub-discipline, interest in the quality and standard of living of broad social groups (e.g. sociology, economics, history) or individuals (e.g. psychology) exists in all of them. Even an attempt at a cursory look at today's socio-economic and political situation in the world leaves no doubt as to what is the object of concern and indignation for the inhabitants of all continents. In some countries this struggle takes the form of direct strikes with the reaction from the police and the military (e.g. Chile, Bolivia, France, Greece, China), while in others it assumes less organised forms such as strikes, peaceful street protests, parliamentary and judicial battles. In all cases, however, it is all about social welfare, which, while being achieved in different ways, sets the course for different actions and mobilisation of individuals and broad social groups.

\section{TRYING TO DEFINE SOCIAL WELFARE}

The wide range of meanings of social welfare, and therefore problems with its definition, is a consequence of the wealth of theoretical perspectives and empirical attempts to operationalise the concept (Baranowski 2017). Furthermore, it should be added that this concept covers many determinants of different scope (from the question of freedom through material conditions to the subjective conviction of personal security and the future of the community). It is difficult to imagine the possibility of developing a satisfactory definition of social welfare that would respond to the repeatedly exclusive requirements of researchers and practitioners of social life (cf. the fiasco of determined reconstructionism in the construction of concepts - Oppenheim 1981 and Sartori 1984). The following proposal, therefore, does not aspire to be a universal interpretation, since such an interpretation does not and cannot exist. However, given the sociological perspective, the restrictive attempts to define social welfare, whether from a (cognitive) psychology or (welfare) economics perspective, are not acceptable. Thus, the proposal presented here is not so much to conduct psychological (referred to as subjective well-being) or economic (as part of the classical school of economics) criticism of welfare, but rather to include or incorporate the "key" components of these approaches in a broader sociological context.

Because sociology is a positivist science in the sense that it deals with social reality as it is, the opposite of social welfare, which has been described as "welfare scarcity," has been introduced into the conceptual model (which plays a heuristic role). At the individual level, the concepts of well-being and ill-being, well established in cognitive psychology, correspond to them (see Fig. 1). 
Figure 1. Conceptual model of relations between social welfare and welfare scarcity (and their equivalents at the subjective level)

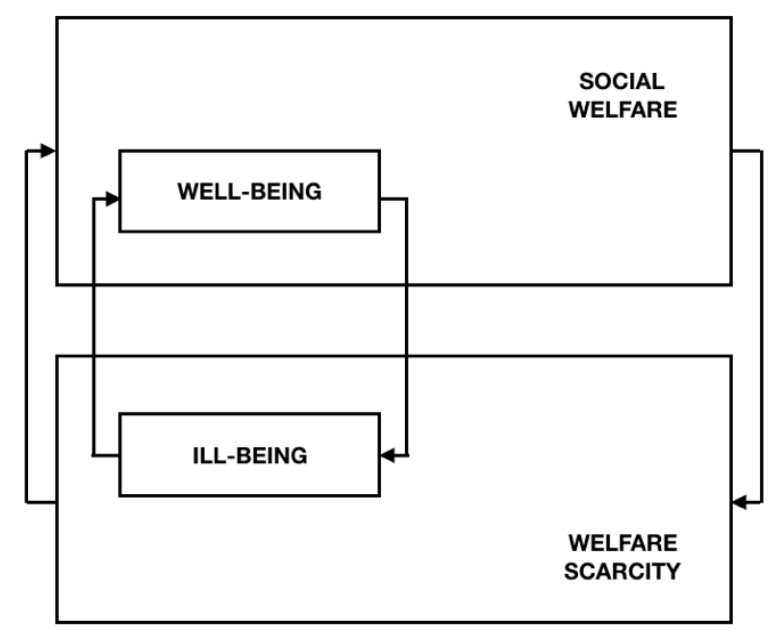

Source: own elaboration.

The relationship both between social welfare and welfare scarcity, as well as between well-being and ill-being and between social welfare and well-being and welfare scarcity and ill-being are two-way streets, which means that they condition each other. Taking the category of satisfying needs in the broadest sense (which means not only their structuring, as in Maslov's case but also their open and evolving character) as the core of social welfare, it is easy to understand the meaning of welfare scarcity, meaning the impossibility (deficit) of satisfying them. An important role in the conceptualisation of welfare and its opposite is played by the micro-level, which in this context means the subjective perception of satisfaction (well-being) or discontent (ill-being) with the state of life as a whole or in a more fragmented way. The micro-level is conditioned by the macro level, but also has a secondary impact, i.e. it co-creates a higher order perspective (see Figure 2).

Taking into account the above, it can be concluded that social welfare concerns the degree to which the material and non-material needs of a society are satisfied both at the collective (supra-individual) and individual (subjective) level. The last two levels should be considered together since in the sociological perspective (which places particular emphasis on the supra-individual) the subjective component is shaped by what is social, while what is social is formulated at the micro-level.

Social welfare understood in this way corresponds to and is appropriate for the analysis of the phenomenon of the welfare state, which, according to Thomas H. Marshall's approach, complements and at the same time makes the previously introduced civil and political rights a reality (1992 [1949]). This is because "[t]he poor vote in much smaller numbers than anyone else. So there is little political risk in penalising them: just how 'hard' are such choices?” (Judt 2010: no pages). Even in the light of this example, one can see that the perspective of "classical" political economics or, by analogy, political sociology are more appropriate approaches to the analysis of society as a whole. 
Figure 2. Social welfare - welfare scarcity and well-/ill-being

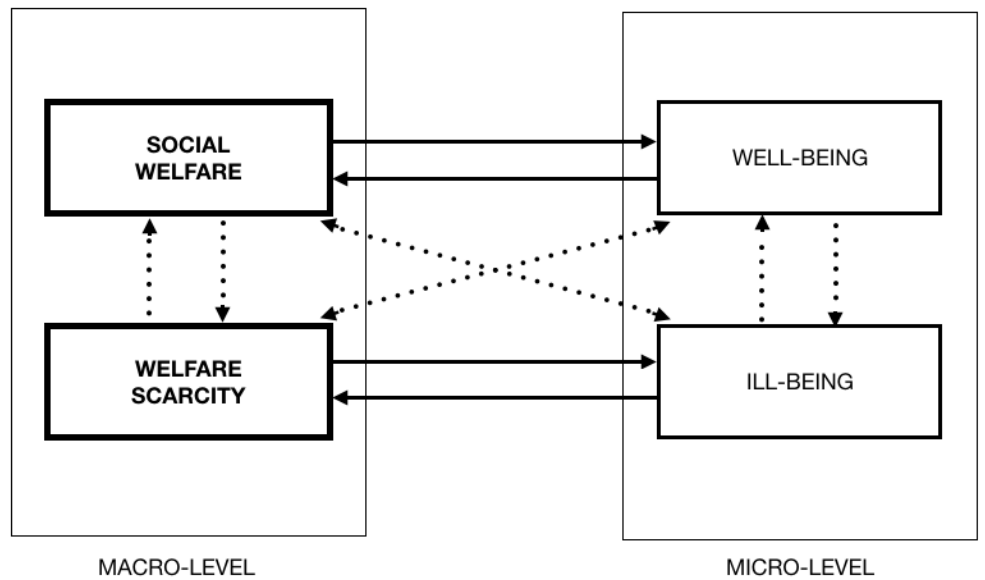

Source: own elaboration.

The proposed approach to social welfare, which takes into account the level of subjective beliefs, avoids the difficulties associated, for example, with the concept of affluenza, understood as "a painful, contagious, socially transmitted condition of overload, debt, anxiety, and waste resulting from the dogged pursuit of more" (De Graaf, Wann and Naylor 2014:1). When considering the problems of achieving social welfare, it is worth keeping in mind a kind of paradox that today more people suffer from obesity than from hunger around the world (WHO 2018). The welfare sociology also has to deal with the explanation of such contradictions.

\section{SOCIAL WELFARE AND THE WELFARE STATE}

Reducing social welfare to the institutions of the welfare state constitutes an issue that tends to be often overlooked or simply ignored, in spite of its prominence in contemporary welfare research. The reflection on the shape and specificity of the welfare state in an institutionalised form, sometimes - although not synonymous - referred to as social or public policy (also in the plural), dates back to the social security programme introduced by the Reich Chancellor, Otto von Bismarck, in 1880. The form of fully-formed welfare states after the Second World War, when the transition from "warfare" to "welfare" (in the context of the Cold War, cf. Light 2003), understood as protection against basic life risks, took place. In order to reduce these risks and eliminate the main social problems - Wolfgang Streeck (2016:4) spoke of "'post-war settlement' of social-democratic capitalism" - institutions of the welfare state were established to counteract the most important social ills (with unemployment, living conditions of the elderly, problems of housing, education and health care at the forefront).

Although studies of welfare state regimes are extraordinarily diverse and fruitful, it should not be forgotten that the very concept of social welfare is broader in scope. 
When examining the institutions of welfare states, we examine selected aspects of social welfare, but the title phenomenon contains a much broader (also non-institutional) perspective.

Social welfare is achieved through state institutions (welfare state), the market (both in terms of the performance of public tasks by private entities and through the consumption of goods and services), charities, but also through the family in the broadest sense. The definition of social welfare through the prism of satisfying needs gives a wide range of possibilities to apply such a phenomenon to theoretical (aimed at describing and explaining the level of social development) and practical (i.e. empirical, where hypotheses based on theoretical explorations are tested) analyses. The perspective of the welfare state focuses primarily on collective needs, which corresponds to the sociological understanding of social institutions in general. These collective needs are met free of charge by state institutions, which means that they perform, among other things, directly (a) an emancipatory function, and indirectly (b) a socialisation function. The former involves the organisation of social conditions conducive to individual and supra-individual development, which are possible through liberation (also understood as a change in cultural practices) and granting certain rights to particular social categories. The socialisation function, in this context, means the process of preparing individuals to undertake specific tasks in society, subject to a control mechanism, which in turn is subordinated to a sanctioned (legitimacy) social order.

Particularly as part of the socialisation function, researchers of social welfare from the institutional side should remember that as Kaaryn S. Gustafson (2011:1) noted, "[w]elfare rules assume the criminality of the poor. Indeed, the logics of crime control now reign supreme over efforts to reduce poverty or to ameliorate its effects" (cf. also Wacquant 2009).

Studies of welfare state regimes have a relatively long history, given that their institutional origins are linked to the end of World War II (Wilensky and Lebeaux 1958; Hunter 1958; Titmuss 1974; Mishra 1981). One of the most common typologies of welfare states was proposed by the Danish sociologist Gøsta Esping-Andersen (1990). He distinguished the three main regimes of capitalist welfare states: liberal, conservative and social democratic (1990: 26-29).

Today, there is a lively reflection to the research on attitudes and opinions towards the institutions of the welfare state, which are based on systematic opinion surveys carried out as part of such projects like the European Social Survey or the World Value Survey. The juxtaposition of 'classical' surveys of welfare state models (based on macroeconomic or macrosocialological indicators) with opinion surveys on them gives additional possibilities to take into account the dynamics of change in the perception of these institutions (Roosma, van Oorschot and Gelissen 2014; Svallfors 2003, 2012; Van Oorschot and Meuleman 2012). Moreover, as Timo Toikko and Teemu Rantanen (2017: 202) noted, "the significance of the welfare state model is seen among citizen's social-political attitudes”. 
Figure 3. The Conceptual link between welfare state regime and welfare attitudes

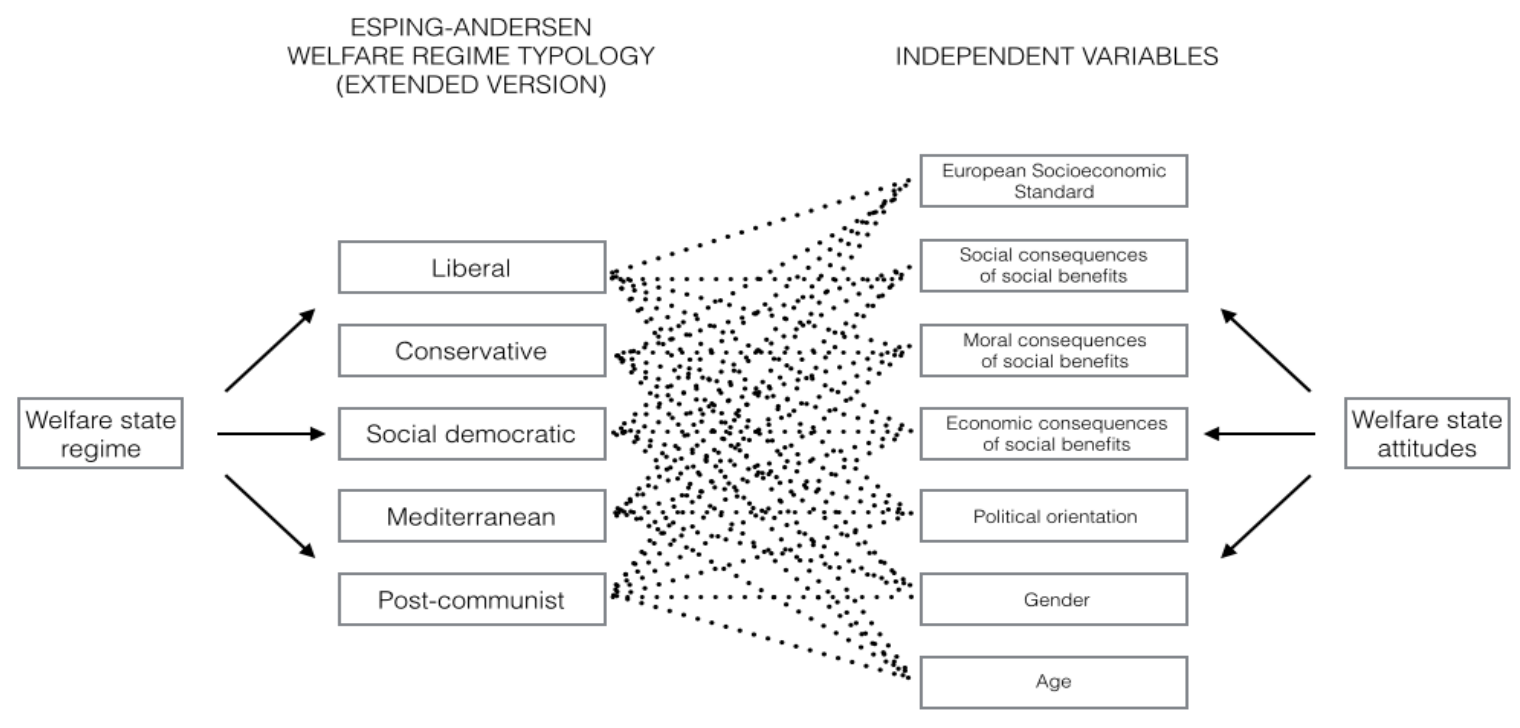

Source: own elaboration.

The potential form of the relationship between welfare state models and welfare attitudes research (based on the example of a special module Welfare state scope and responsibilities in ESS Round 8) is presented in Figure 3. It uses an extended Esping-Andersen typology and components of the survey of respondents' attitudes towards welfare state institutions. The analysis of respondents' opinions and/or attitudes on individual welfare state solutions (or their lack) provides valuable empirical material not only for public policy theoreticians but also for practitioners and politicians. Practitioners receive representative results of "bottom-up" evaluation of implemented solutions together with their multidimensional evaluation, while politicians receive data on social expectations of social policies implemented by state institutions. For the welfare sociology, the knowledge about institutional solutions and their impact on the level and quality of social life, as well as systematic surveys of citizens' opinions in this respect constitute invaluable empirical material on the phenomenon of social welfare in a sense outlined above.

\section{SOCIAL WELFARE AND LABOUR SOCIETY}

The social welfare as proposed here can also be seen through the prism of work, because “(...) we are driven by the fact that the 'self' is constituted, at least for most of us, by membership in the labor force, as a member of either the job bourgeoisie - the "professions' - or the working class" (Aronovitz and Di Fazio 1996: 328-329). Even more importantly, from the point of view of holistically understood welfare in a capitalist society, is that paid work is understood as "a socially and psychologically constructed 'need' shared by those who have been successfully habituated to think that the link between holding a job and having 'dignity' is a given. Put bluntly, in this view the self 
is identical to its place in the paid labor force. No job, no (secure) self" (Aronovitz and Di Fazio 1996:329). The subjective component of work understood in this way is as essential as the materialistic dimension of earnings in the capitalist economy. The aforementioned components, i.e. need and dignity, determine the key framework for the interpretation of the main activities of individuals within the dominant socio-economic system. The (free) market ideology and its undeniable success in understanding world domination "produces" a reality in which "individuals, not the economic and social system, are ultimately responsible for their fate; the market adjusts itself at a level approximating full employment, and any joblessness is 'frictional' - that is, temporary - for responsible and able-bodied individuals" (Aronovitz and Di Fazio 1996: 329). It is worth looking at this problem from the philosophical-political analyses of Nancy Frazer and Axel Honneth (2003), where the terms "recognition" and "redistrubution" provide a research perspective.

The form of pressure exerted on the individual by the dominant capitalist system has its consequences both at the individual level, i.e. subjective (well-being versus ill-being) and supra-individual (social welfare versus welfare scarcity). The issue of work and its impact on the realisation of life chances of individuals is also one of the main aspects of contemporary welfare state institutions. It is the labour market that determines a significant field of activity for public policies (employment policy, active social policy, the issue of unemployment and programmes to counteract it, the employment guarantee programme, making social benefits dependent on work, flexicurity, etc.). At the same time, contemporary research on work increasingly refers to the notions of precariousness (Standing 2011, 2014), working poor (Shipler 2004), bullshit jobs (Graeber (2019 [2018]), NINJA (No Income, No Jobs and No Assets), NEET (Neither in Employment nor in Education and Training), the boomerang generation. (Stiglitz 2012:80) and even wrongly ridiculed "bamboccioni" (Honwana 2014: 28-40).

The very discourse in the prevailing socio-economic system about work, which will not be reduced to 15 hours a week by 2030, as Keynes prophesied in 1930, is part of “capitalism's ability to assimilate critique" (Boltanski and Chiapello 2007: xv).

As Susan George (1999) noted, when she described the success of neoliberalism, “(...) the ideological and promotional work of the right has been absolutely brilliant. They have spent hundreds of millions of dollars, but the result has been worth every penny to them because they have made neo-liberalism seem as if it were the natural and normal condition of humankind. No matter how many disasters of all kinds the neo-liberal system has visibly created, no matter what financial crises it may engender, no matter how many losers and outcasts it may create, it is still made to seem inevitable, like an act of God, the only possible economic and social order available to us". It is hard not to admit that the American political scientist is right that the neoliberal project has been extraordinarily successful and appears to people as - let us use the term Margaret Thatcher - TINA (There is no alternative). But on the other hand, the various strategies of resistance to the neoliberal variety of capitalism are in favour of the TATA option! (There are thousands of alternatives!) (cf. George 2002).

Social welfare - in a sense adopted in this article - considered through the prism of the labour market should not only be limited to productive work (i.e. production 
of goods) but should also take into account the specificity of reproductive work (i.e. production of life). Only such a perspective allows us to see the essence of the neoliberal reality in its full glory, as it goes beyond narrowly understood employee research, limited to workplaces. Satisfying (or, to be more precise, not satisfying) individual and social needs also takes place outside the workplace; hence reproductive work, which is dispersed throughout society, opens up completely new fields of research (cf. Waring 1998).

Stanley Aronowitz and William Di Fazio noticed that: "Capital fears its own moving spirit. Vast quantities of labor are set free from the labor process, but rather than fostering full individual development, production and reproduction penetrate all corners of the life world, transforming it into a commodity world not merely as a consumption but also in the most intimate processes of human interaction" (Aronovitz and Di Fazio 1996: 339). Then they add that "Intellectual labor, its ideology of professional autonomy in tatters as a result of its subordination to technoscience and organisation, becomes a form of human capital the components of which are specialised knowledge and differentially accumulated cultural capital determined mainly by hierarchically arranged credentials" (Aronovitz and Di Fazio 1996: 339).

Neoliberal capitalism is capable of appropriating various forms of resistance developed against it. Although the forms result from multifaceted strategies of socialising resources that have been commoditised by capitalism and recovered again to serve the widest possible society or communities, the result is the opposite. Let us take the example of new technologies that have the potential to change many spheres of society's functioning, from politics, through leisure, to the world of work and social security (Unconditional Basic Income). Today, economy platforms, or access, gig or sharing, not only do not expand the field of emancipation and socialisation, but are more sophisticated forms of exploiting the workforce or resources of individuals to increase the profits of new industry giants, known as FAANG (Facebook, Amazon, Apple, Netflix and Google), to which several more players such as Microsoft and Uber can be added. Naturally, there is an area of new network technologies that strengthen non-market sharing mechanisms. However, they are unable to transform the capitalist system, absorbing these "new" innovations into commodity logic.

It is not just about new technologies, as Harry Cleaver (1993:37) pointed out almost two decades ago that “(...) our inability to avoid being divided and conquered, i.e., to avoid the successful decomposition of our power. At a global level, capital's ability to impose localised hunger, disease and starvation in the 1970s and 1980s (especially the famines in Africa), through its ability to impose austerity (unemployment and falling real income) and police repression (e.g. Mexico, Brazil, Mozambique, the American rust belt, the ghettos of Washington and Los Angeles), to its ability to impose war and devastation (e.g., Panama, the Persian Gulf), the success of these terribly destructive counterattacks have depended on preventing the mobilisation of outside support through the isolation of the targeted populations - in part through the manipulation of circuits of information and communication".

When studying the phenomenon of social welfare and its opposite (welfare scarcity), it is impossible to abstract from historical facts, which show the political nature 
of capitalism. Austerity politics (or "harsh austerity policies", Toussaint 2019:158) is linked to the politics of fear, which affects both material welfare scarcity and subjective ill-being. In the context of poverty in Senegal, Rosalind Fredericks (2018) even speaks of "garbage citizenship", or rather, as the author noted, "understanding urban infrastructural citizenship in the wake of neoliberal development" (2018: 26). The book itself has the following purpose: "The provocations of Dakar's garbage citizens are used to reflect on the possibilities for building more just urban infrastructures" (2018: 26), which is ultimately also about social welfare.

\section{CONCLUSIONS}

Citing a book by economists from the University of California at Berkeley Emmanuel Saez and Gabriel Zucman The Triumph of Injustice, Christopher Ingraham (2019) from The Washington Post stated that their study "finds that in 2018, the average effective tax rate paid by the richest 400 families in the country was 23 percent, a full percentage point lower than the 24.2 percent rate paid by the bottom half of American households". A situation in which the wealthiest people (super-rich) pay lower taxes in a given society than the working class not only makes the social and economic system blatantly unjust but also prevents in many ways the introduction of social welfare in society as a whole (cf. Husson 2015; Piketty 2014).

In fact, the (free) market system is applied to the economically weakest parts of society (cf. Markowska-Manista 2017). At the same time, super-rich and super corporations can count on public support from state institutions in many ways (repayment of debts resulting from unprofitable, greedy or simply breaking the law by large economic entities, on the one hand, special tax discounts and even public subsidies for private investment, etc. on the other hand - more broadly in the context of the recent crisis, compare Toussaint and Millet 2010).

When we examine society in the context of social welfare, we have to keep in mind that “(...) individual prosperity is curtailed in the presence of social calamity. That things are going well for me personally is of little consolation in my family, my friends and my community are all in dire straits. My prosperity and the prosperity of those around me are intertwined. Sometimes inextricably" (Jackson 2009:1).

Research on social welfare, e.g. solely in the aspect of - let us use Tim Jackson's term - "individual prosperity", although cognitively stimulating, does not give a full overview of the impact of diverse social, political, economic or cultural determinants. And one must bear in mind that these determinants overlap, which further complicates the possibilities of describing and explaining (not to mention trying to predict) the phenomenon of social welfare or its opposite. Additionally, as Noam Chomsky pointed out, the entities that gain the most within the capitalist system do not remain passive. Well, "The smart way to keep people passive and obedient is to strictly limit the spectrum of acceptable opinion, but allow very lively debate within that spectrum (...)" (Chomsky, Barsamian and Naiman 2003: 43). Thus, in the context of welfare attitudes research, one should consider - often very subtle and sophisticated - methods of manipulating public opinion (cf. Bernays 1928; Chomsky 1991; Pierzchalski 2017). 
How timely today is George Orwell's 1984 passage, in which he stated:

All that was required of them was a primitive patriotism which could be appealed to whenever it was necessary to make them accept longer working-hours or shorter rations. And even when they became discontented, as they sometimes did, their discontent led nowhere, because being without general ideas, they could only focus it on petty specific grievances. The larger evils invariably escaped their notice (Orwell 2018: 92).

When studying the conditions of social welfare, we cannot overlook "the larger evils"; when studying this social phenomenon, we must have a broad theoretical-methodological overview capable of grasping a comprehensive picture of the phenomenon. Including even those seemingly unrelated and distant fragments of it which prey on lofty concepts of patriotism, justice and faith.

FUNDING: This research received no external funding.

CONFLICTS OF INTEREST: The author declares no conflict of interest.

\section{REFERENCES}

Aronowitz, Stanley and William DiFazio. 1996. “Jobless Future?” Pp. 328-358 in The Jobless Future. Sci-Tech and the Dogma of Work, edited by S. Aronovitz and W. DiFazio. Minneapolis: University of Minnesota Press.

Baranowski, Mariusz. 2017. "Welfare Sociology in Our Times. How Social, Political, and Economic Uncertainties Shape Contemporary Societies.” Przegląd Socjologiczny 66(4): 9-26. DOI: 10.26485/PS/2017/66.4/1.

Bernays, Edward L. 1928. Propaganda. New York: H. Liveright.

Boltanski, Luc and Ève Chiapello. 2007. The New Spirit of Capitalism. Translated by G. Elliott. London and New York: Verso.

Chomsky, Noam. 1991. “Force and Opinion.” Magazine July-August. Retrieved December 5, 2019 (https://chomsky.info/199107_/).

Chomsky, Noam, David Barsamian and Arthur Naiman. 2003. The Common Good. Tucson, Arizona: Odonian Press.

Cleaver, Harry. 1993. "Marxian Categories, the Crisis of Capital and the Constitution of Social Subjectivity Today.” Common Sense 14: 32-55. https://commonsensejournal.org.uk/wp-content/uploads/sites/6/2010/08/CommonSense14.pdf

Daunton, Martin. 2007. Wealth and Welfare: An Economic and Social History of Britain, 1851-1951. Oxford: Oxford University Press.

De Graaf, John, David Wann and Thomas H. Naylor. 2014. Affluenza: How Overconsumption is Killing Us - and How We Can Fight Back. Third edition. San Francisco: Berrett-Koehler Publishers, Inc.

Esping-Andersen, Gøsta. 1990. The Three Worlds of Welfare Capitalism. Cambridge: Polity Press.

Forder, Anthony. 1984. “The Social Sciences and Welfare.” Pp. 1-25 in Theories of Wel- 
fare, edited by A. Forder, T. Caslin, G. Ponton, and S. Walklate. London, Boston, Melbourne and Henley: Routledge \& Kegan Paul.

Fraser, Nancy and Axel Honneth. 2003. Redistribution or Recognition? A Political-Philosophical Exchange. Translated by J. Golb, J. Ingram, and Ch. Wilke. London and New York: Verso.

Fredericks, Rosalind. 2018. Garbage Citizenship: Vital Infrastructures of Labor in Dakar, Senegal. Durham and London: Duke University Press.

Galbraith, John K. 1998. The Affluent Society. Fortieth Anniversary Edition. Boston and New York: Houghton Mifflin Company.

George, Susan. 1999. "A Short History of Neoliberalism." Paper presented at the Conference on Economic Sovereignty in a Globalising World, Bangkok, 24-26 March 1999. Retrieved November 5, 2019 (https://www.tni.org/en/article/short-history-neoliberalism).

George, Susan. 2002. “Another World Is Possible.” The Nation Magazine, February 18. Retrieved November 5, 2019 (http://www.thirdworldtraveler.com/Dissent/AnotherWorldPossible.html).

Graeber, David. 2019. Bullshit Jobs. A Theory. London: Penguin Books.

Gustafson, Kaaryn S. 2011. Cheating Welfare: Public Assistance and the Criminalization of Poverty. New York and London: New York University Press.

Honwana, Alcinda. 2014. “'Waithood': Youth Transitions and Social Change.” Pp. 2840 in Development and Equity: An Interdisciplinary Exploration by Ten Scholars from Africa, Asia and Latin America, edited by D. Foeken, T. Dietz, L. de Haan and L. Johnson. Boston: Brill.

Hunter, Floyd. 1958. „Industrial Society and Social Welfare. By Harold Wilensky and Charles Lebeaux. New York: Russell Sage Foundation, 1958." Social Forces 37(1): 84-85. DOI: doi: https://doi.org/10.2307/2573791

Husson, Michel. 2015. "Capital in the Twenty-First Century by Thomas Piketty. 'Wealth of Data, Poverty of Theory.” Historical Materialism 23(1): 70-85. DOI: https://doi. org/10.1163/1569206X-12341390

Ingraham, Christopher. 2019. "For the first time in history, U.S. billionaires paid a lower tax rate than the working class last year." The Washington Post, Oct. 8, 2019. Retrieved November 5, 2019 (https:/www.washingtonpost.com/business/2019/10/08/first-time-history-us-billionaires-paid-lower-tax-rate-thanworking-class-last-year/).

Jackson, Tim. 2009. Prosperity without Growth: Economics for a Finite Planet. London and Sterling, VA: Earthscan.

Judt, Tony. 2010. Ill Fares the Land. New York: The Penguin Press. (Digital edition) Light, Jennifer S. 2003. From Warfare to Welfare: Defense Intellectuals and Urban Problems in Cold War America. Baltimore and London: The Johns Hopkins University Press.

Markowska-Manista, Urszula. 2017. “The Written and Unwritten Rights of Indigenous Children in Central Africa - Between the Freedom of 'Tradition' and Enslavement for 'Development." Pp. 127-142 in Symbolic Violence in Socio-Educational Contexts: A Post-Colonial Critique, edited by A. Odrowąż-Coates and S. Goswami. 
Warszawa: Wydawnictwo Akademii Pedagogiki Specjalnej.

Marshall, Thomas H. 1992. Citizenship and Social Class. London: Pluto Press.

Marx, Karl and Frederick Engels. 1948. Manifesto of the Communist Party. New York: International Publishers.

Marshall, Thomas H. 1961. “The Welfare State: A Sociological Interpretation.” European Journal of Sociology/Archives Européennes de Sociologie 2(2): 284-300. DOI: https://doi.org/10.1017/S0003975600000448.

Mishra, Ramesh. 1981. Society and Social Policy. Theories and Practice of Welfare. London and Basingstoke: The Macmillan Press.

Oppenheim, Felix. 1981. Political Concepts: A Reconstruction. Oxford: Blackwell.

Orwell, George. 2018. 1984. No city: Planet Book.

Pierzchalski, Filip. 2017. Political Leadership in Morphogenetic Perspective. Frankfurt am Main: Peter Lang Edition.

Piketty, Thomas. 2014. Capital in the Twenty-First Century. Translated by A. Goldhammer. Cambridge, MA.: Harvard University Press.

Pontusson, Jonas. 2005. Inequality and Prosperity: Social Europe vs. Liberal America. Ithaca and London: Cornell University Press.

Roosma, Femke, Wim van Oorschot and John Gelissen. 2014. "The Preferred Role and Perceived Performance of the Welfare State: European Welfare Attitudes form a Multidimensional Perspective.” Social Science Research 44: 200-210. DOI: 10.1016/j.ssresearch.2013.12.005.

Sartori, Giovanni, ed. 1984. Social Science Concepts. Beverly Hills and London: Sage.

Shipler, David K. 2004. The Working Poor: Invisible in America. New York: Knopf.

Standing, Guy. 2011. The Precariat: The New Dangerous Class. London and New York: Bloomsbury Academic.

Standing, Guy. 2014. A Precariat Charter: From Senizens to Citizens. London and New York: Bloomsbury Academic.

Stiglitz, Joseph E. 2012. The Price of Inequality: How Today's Divided Society Endangers our Future. New York and London: W.W. Norton \& Company.

Streeck, Wolfgang. 2016. How Will Capitalism End? Essays on a Falling System. London and New York: Verso.

Svallfors, Stefan. 2003. "Welfare Regimes and Welfare Opinions: A Comparison of Eight Western Countries.” Social Indicators Research 64(3): 495-520.

Svallfors, Stefan. 2012. “Welfare States and Welfare Attitudes.” Pp. 1-24 in Contested Welfare State: Welfare Attitudes in Europe and Beyond, edited by S. Svallfors. Stanford: Stanford University Press.

Titmuss, Richard M. 1974. Social Policy: An Introduction. New York: Pantheon Press.

Toikko, Timo and Teemu Rantanen. 2017. "How Does the Welfare State Model Influence Social Political Attitudes? An Analysis of Citizens' Concrete and Abstract Attitudes toward Poverty." Journal of International and Comparative Social Policy 33(3): 201-224. DOI: 10.1080/21699763.2017.1302892.

Toussaint, Éric. 2019. The Debt System: A History of Sovereign Debts and Their Repudiation. Chicago, Illinois: Haymarket Books.

Toussaint, Éric and Damien Millet. 2010. Debt, the IMF, and the World Bank. Sixty Ques- 
tions, Sixty Answers. New York: Monthly Review Press.

Van Oorschot, Wim and Bart Meuleman. 2012. "Welfarism and the Multidimensionality of Welfare State Legitimacy: Evidence from the Netherlands, 2006.” International Journal of Social Welfare 21(1): 79-93. DOI: 10.1111/j.1468-.-2397.2010.00779.x.

Wacquant, Loïc J. D. 2009. Punishing the Poor: The Neoliberal Government of Social Insecurity. Durham: Duke University Press.

Waring, Marilyn. 1998. If Women Counted: A New Feminist Economics. San Francisco: Harper \& Row.

WHO. 2018. “Obesity and Overweight.” World Health Organization, 16 February 2018. Retrieved November 5, 2019 (https://www.who.int/en/news-room/fact-sheets/ detail/obesity-and-overweight).

Wilensky, Harold L. and Charles N. Lebeaux. 1958. Industrial Society and Social Welfare. New York: Russell Sage Foundation.

\section{BIOGRAPHICAL NOTE}

Mariusz Baranowski is assistant professor of sociology at the Adam Mickiewicz University in Poznań, Poland.

OPEN ACCESS: This article is distributed under the terms of the Creative Commons Attribution Noncommercial License (CC BY-NC 4.0) which permits any noncommercial use, and reproduction in any medium, provided the original author(s) and source are credited. 
